педагога, сприяє розвитку індивідуальних професійних якостей, накопиченню професійного досвіду, що передбачає непереривний розвиток і самовдосконалення.

\title{
Література
}

1. Бухбиндер В. А. Основные типы уроков иностранного языка и их дидактико-методические модели / В. А. Бухбиндер // Общая методика обучения иностранным языкам : [хрестоматия] / сост. Леонтьев А. А. - М. : Русский язык, 1991. С. 137-139. 2. Гаврилова Т. А. Психологический анализ урока : [метод. пособие] [Электронный ресурс] / Т. А. Гаврилова. - Уссурийск, 2000. Режим доступа: http://pdb.uspi.ru/book_1544/ 3. Игна О. Н. Анализ урока в оценке учителя иностранного языка [Электронный ресурс] / О. Н. Игна. - Режим доступа:http://pedsovet.org/component/ option,com mtree/task,viewlink/link id,5940/Itemid,118/

4. Кузовлев В. П. Четыре аспекта образовательного потенциала урока [Электронный ресурс] / В. П. Кузовлев. - Режим доступа: http://iyazyki.ru/2011/12/potentsial-uroka/ 5. Пантилеева М. C. O некоторых способах развития эмоционального интеллекта младших школьников на уроках английского языка [Электронный ресурс] / М. С. Пантилеева. - Режим доступа: http://eng.1september.ru/ article.php?ID=200701804 6. Шипилова С. P. Современный личностно-ориентированный урок [Электронный ресурс] / C. Р. Шипилова. - Режим доступа: http://nsportal.ru/nachalnayashkola/blog/sovremennyi-lichnostno-orientirovannyi-urok. ДВНЗ «Криворізький національний університет»

\section{ЕМОЦЙНИЙ АСПЕКТ У ФОРМУВАННІ КОМУНІКАТИВНОЇ КОМПЕТЕНЦІЇ УЧНІВ ПІД ЧАС НАВЧАННЯ МОРФОЛОГІЇ}

У статті розкрито емочійний аспект у формуванні комунікативної компетениії учнів, запропоновано приклади завдань, які можуть бути використані в процесі навчання морфологї.

Ключові слова: емоції, види емочій, комунікативна компетенція, навчання морфологї.

В статье раскрыт эмоциональный аспект в формировании коммуникативной компетенции учащихся, предложены примеры заданий, которые могут быть использованы в прочессе изучения морфологии.

Ключевые слова: эмоции, виды эмочий, коммуникативная компетенция, обучение морфологии. 
The article revealed the emotional aspect in the formation of the communicative competence of students offered examples of jobs that can be used in the study of the morphology.

Key words: emotions, types of emotions, communicative competence, training morphology.

Уміння спілкуватися в різних ситуаціях із дотриманням норм літературної мови є однією 3 найголовніших соціальних вимог, що висуваються до школярів на сучасному етапі модернізації мовної освіти. Вільне володіння державною мовою $\epsilon$ важливим чинником соціалізації випускників середньої школи, оскільки забезпечує доступ до наукових, культурних, духовних надбань українського народу, є засобом реалізації особистісного потенціалу кожного учня. 3 огляду на це Концепція мовної освіти, Державний стандарт базової і повної середньої освіти передбачають формування комунікативної компетенції учнів, що пов'язана 3 оволодінням усіма видами мовленнєвої діяльності, охоплює не тільки знання мовної системи, а й дотримання соціальних норм спілкування, правил мовленнєвої поведінки.

Формування комунікативної компетенції - одна 3 основних проблем сучасної методики навчання української мови, оскільки відсутність належного рівня практичних умінь орієнтуватися в ситуації спілкування, відповідно до комунікативної мети добирати мовні засоби для вираження думок і почуттів негативно позначається на якісних характеристиках мовлення, духовному й інтелектуальному становленню особистості учнів.

Науковці (3. Бакум, О. Горошкіна, Т. Донченко, С. Караман, В. Мельничайко, М. Пентилюк, Г. Шелехова, А. Ярмолюк) у своїх роботах звертаються до проблеми формування комунікативної компетенції школярів, намагаються віднайти ефективні шляхи реалізації комунікативної методики навчання української мови. Незважаючи на значні успіхи вчених, низка завдань потребує розв'язання, зокрема, дослідження емоційного аспекту у формуванні комунікативної компетенції школярів.

Відомо, що рідна мова формує розумові й емоційні якості людини, є засобом не тільки розумового, а й емоційного спілкування. Під впливом почутого або прочитаного слова, у природних умовах навчально-виховного процесу школярі 
виявляють позитивні чи негативні емоції, допомогти усвідомити які - важливе завдання вчителя.

Поділяємо думку М. Пентилюк, яка зауважує, що учні повинні розуміти не тільки сутність виразності мови, але й засвоїти способи вираження емоційності та експресивності в мовленні під час спілкування [4, с. 32].

Mета cmammi: розкрити емоційний аспект у формуванні комунікативної компетенції учнів.

Формування духовно багатої мовної особистості, яка володіє вміннями й навичками вільно, комунікативно доцільно користуватися засобами рідної мови в усіх видах мовленнєвої діяльності, $\epsilon$ основною метою навчання рідної мови на сучасному етапі. Вільне володіння мовою $є$ інтегральною якістю мовної особистості, яку можна сформувати лише з урахуванням усіх аспектів і закономірностей навчання мови.

Процес засвоєння мови довготривалий і складний; комунікативні якості мовлення виявляються тільки в процесі мовленнєвої діяльності, а отже, потребують постійної уваги. Виразність, емоційність мови діти вчаться відчувати змалечку, однак усвідомлене вивчення мови допомагає їм проникнути в тонкощі смислових відтінків мовних одиниць, навчитися оцінювати їх виразність, стилістичну доцільність [4, с. 32].
Науковці
(О. Бистрова,
О. Горошкіна,
Т. Донченко, М. Жинкін, I. Зимня, Т. Ладиженська, О. Леонтьєв, М. Пентилюк) справедливо закликають вивчати мову в процесі мовленнєвої діяльності, наголошують на необхідності створення на уроці таких умов, які б сприяли бажанню дітей висловлюватися, взаємодіяти із співрозмовником, впливати на нього. Практична спрямованість навчання мови передбачає оволодіння школярами всіма видами мовленнєвої діяльності з метою спілкування, що забезпечує формування комунікативної компетенції учнів.

За визначенням О. Бистрової, комунікативна компетенція - це знання, уміння і навички, необхідні для розуміння чужих і породження власних програм мовленнєвої поведінки, адекватних цілям, сферам, ситуаціям спілкування [1, с. 5].

Комунікативна компетенція спрямована на розв'язання таких основних завдань: ефективно отримувати інформацію; ефективно передавати інформацію; досягати поставленої мети через переконання співрозмовника і спонукання його до дії; отримувати додаткову інформацію про співрозмовника, зокрема, на основі умінь відрізняти відтінки інтонації й голо- 
су визначати його емоційний стан; здійснювати позитивну самопрезентацію - тобто справляти приємне враження на співрозмовника або читача на основі володіння культурою мовлення.

Процес спілкування викликає різні емоційні стани школярів, тому педагогу необхідно допомогти їм навчитися забезпечувати позитивний вплив на співрозмовника, стримувати вияви негативних емоцій, тобто здійснювати контроль за своєю мовленнєвою поведінкою.

Психологи (Г. Андреєва, Б. Ломов, І. Цимбалюк) у характеристиці спілкування виокремлюють інформаційнокомунікативну, регуляційно-комунікативну й афективнокомунікативну функції, що пов'язані 3 різними аспектами спілкування: комунікативним (обмін інформацією), інтерактивним (взаємодія) та перцептивним (розуміння людини людиною). Афективно-комунікативна функція характеризує емоційну сферу людини, у якій виявляється ставлення до навколишнього середовища, зокрема й соціального.

У науковій літературі для характеристики емоційних станів людини вживаються поняття «емоції» та «почуття», які виражають духовні запити і прагнення людини, іiі ставлення до дійсності. Будь-яка діяльність людини нерозривно пов'язана з виявом емоцій і почуттів. Успіх чи невдача в навчанні, творчій діяльності викликає позитивні або негативні емоції.

За визначенням психологів, емоція - це загальна активна форма переживання організмом своєї життєдіяльності. Розрізняють прості (переживання задоволення від їжі, бадьорості, болю, втоми; властиві і людям, і тваринам) та складні емоції (виникають у результаті усвідомлення об'єкта, що викликав їх, розуміння їхнього життєвого значення, наприклад, переживання задоволення при сприйманні музики, пейзажу) [3, c. 196].

Почуття - специфічні людські, узагальнені переживання ставлення до людських потреб, задоволення або незадоволення яких викликає позитивні або негативні емоції- радість, любов, гордість або сум, гнів, сором тощо [3, с. 197].

У психологічних дослідженнях зазначається: емоціям та почуттям властива полярність, яка виявляється в тому, що кожна емоція, кожне почуття за різних обставин можуть виявлятися протилежно: «радість - горе», «любов - ненависть», «симпатія - антипатія». Полярні переживання мають позити- 
вний або негативний відтінок. Розрізняють стенічні емоції та почуття - ті, що посилюють активність, спонукають до діяльності, та астенічні - ті, що пригнічують людину, зменшують іiі активність. Залежно від індивідуальних особливостей особистості, ïi стану і ставлення до ситуації та об'єктів, що викликають переживання, емоції та почуття виявляються інтенсивно чи ні, бувають довготривалими та короткочасними.

Охоплюючи всі різновиди переживань людини, емоції стають як позитивним чинником у життєдіяльності, підносячи активність організму, так і негативним, пригнічуючи всі його функції. Про це обов'язково потрібно пам'ятати вчителю-словеснику, реалізуючи мету навчання української мови.

Позитивне ставлення учнів до навчального предмета викликає в них бажання пізнати виучуване мовне явище, постійне формування на уроці емоційного ставлення до змісту, який вивчається, сприяє підвищенню рівня знань, умінь і навичок школярів.

О. Горошкіна підкреслює: особливої ваги в навчальному процесі набувають експресивні висловлювання. Значний потік інформації стимулює пошуки педагогів до виражальних засобів, які б будили думку, створювали емоційний настрій, викликали цікавість до виучуваних проблем, а нерідко робили б їх доступнішими [2, с. 68].

Аналіз досліджень учених-методистів дозволяє зазначити, що створення відповідної емоційної атмосфери на уроках української мови спрямоване на формування в учнів позитивного ставлення до предмета загалом і конкретного матеріалу зокрема, тому необхідно заохочувати дітей виявляти емоції та почуття в процесі створення зв'язних висловлювань, виконання ситуативних завдань, вправ проблемно-пошукового характеру. Однак учні повинні пам'ятати про самоконтроль мовленнєвої поведінки, як і будь-якого іншого виду діяльності, адже емоційні стани та форми їх виявлення детермінуються переважно соціальними чинниками.

Вивчення наукової літератури дозволяє говорити про те, що надмірна емоційність у процесі спілкування шкідлива для здоров'я. Аналізуючи реакції активних зон мозку людини, психолінгвісти спостерігали, що на гнівні репліки, вимовлені піднесеним тоном, люди реагують інтенсивним викидом гормонів стресу, причому навіть тоді, коли сердиті слова адресуються зовсім не їм. У такий спосіб працює захисний механізм нашого організму. Тож висновок із цих спостережень 
учені роблять однозначний - у спілкуванні з іншими говорити треба без підвищень тону розмови, оскільки притишене мовлення зберігає здоров'я людини та не псує нерви тим, хто іiі оточує [5, с. 35].

Учні середньої школи мають засвоїти умови успішного спілкування, які враховують емоційний аспект формування комунікативної компетенції: бути ввічливим, привітним і доброзичливим; уважно, не перебиваючи слухати співрозмовника, заохочувати його висловити думку, зацікавлено й доброзичливо вислуховувати іiі; уміти висловити незгоду з позицією співрозмовника так, щоб не образити його; не розмовляти без потреби голосно, не вживати грубих слів, говорити про те, що цікаво адресатові мовлення.

На нашу думку, одним зі шляхів формування комунікативної компетенції учнів є використання на уроках української мови системи завдань, спрямованих на засвоєння учнями правил ефективного спілкування. Наведемо приклади таких, що можуть бути використані під час навчання морфології.

1. Скажіть, які слова називають «чарівними»? Для чого вони потрібні? Побудуйте діалог, використовуючи «чарівні» слова і фрази.

2. Як ви розумієте вислови: «Ласкаве слово - як весняний день», «Будь ласка не кланяється, а спасибі спини не гне», «Від погляду молоко кисне»? Доберіть до прикметників антоніми, складіть з антонімічними парами речення.

3. Доведіть, що особливості спілкування людей позначаються на їхніх стосунках, настрої, самопочутті. Складіть правила ведення розмови, використовуючи дієслова в неозначеній формі.

4. Уявіть ситуацію: ви не підготувалися до уроку і не попередили про це вчителя. Опишіть свої емоції в період очікування прізвища учня, якого вчитель викликав до дошки. Слова на позначення емоційного стану запишіть, в іменниках визначте рід і відміну.

5. Поясніть значення слів тактовний і делікатний, виконайте морфологічний розбір одного з них. Чи потрібний такт у випадках, коли критикуєш товариша?

6. Опишіть випадок, що стався на уроці та спричинив особливо радісний настрій. Запишіть прислівники, використані в описі.

7. Скажіть, чи відчуваєте труднощі у спілкуванні з незнайомими людьми. Доберіть синоніми до слова доброзичли- 
вість. Запишіть прислів’я і приказки, у яких характеризується ця риса людини.

Отже, увага до емоційного аспекту виучуваних явищ повинна стати обов'язковою вимогою сучасного уроку української мови. Учителеві важливо пам'ятати, що створення на уроці сприятливої психологічної атмосфери, добір дидактичного матеріалу, який викликає позитивні емоції в учнів, використання цікавих, нестандартних завдань сприяють ефективності навчально-виховного процесу.

\section{Літерататура}

1. Быстрова Е. А. Коммуникативная методика в преподавании родного языка / Е. А. Быстрова // Русский язык в школе. - 1996. № 1. - С. 3-8. 2. Горошкіна О. М. Лінгводидактичні засади навчання української мови в старших класах природничоматематичного профілю : [монографія] / О. М. Горошкіна. - Луганськ : Альма-матер, 2004. - 362 с. З. Максименко С. Д. Загальна психологія : [навч. посібн.] / С. Д. Максименко, В. О. Соловієнко. К. : МАУП, 2000. - 256 с. 4. Методика навчання української мови в середніх освітніх закладах / М. І. Пентилюк, С. О. Караман, О. В. Караман, О. М. Горошкіна та ін.; за ред. М. І. Пентилюк. - К. : Ленвіт, 2004. - 400 с. 5. Федоренко В. Л. Мовні цікавинки. Нестандартні дидактичні матеріали / В. Л. Федоренко. - Х. : Основа, 2006. -320 c. 